\title{
LAYOFF SURVIVORS' PERCEPTIONS OF FAIRNESS AS DETERMINANT OF AFFECTIVE COMMITMENT FOLLOWING DOWNSIZING
}

\author{
ALPER ERTÜRK*
}

Turkish Naval Academy

\begin{abstract}
This study examines the effects of fairness perceptions on the organizational commitment of downsizing survivors during the February 2001 economic crisis. Samples were drawn from bluecollar employees in the service industry. In the statistical analysis, distributive justice was found to be significantly related to the affective commitment of survivors, while procedural justice was not found to be positively associated with the affective commitment of survivors in the service industry. The analysis also yields that interactional justice is strongly and positively associated with the affective commitment of survivors. The managerial and theoretical implications of study are also discussed.
\end{abstract}

Key words: distributive justice, procedural justice, interactional justice, affective commitment.

\section{KÜÇÜLME SONRASI DUYGUSAL BAĞLILIĞI BELIRLEYEN FAKTÖR OLARAK ISSTEN ÇIKARILMAYAN ÇALIŞANLARIN ADALET ALGILARI}

$\ddot{O Z Z T}$

Bu çalışma, Şubat 2001 döneminde personel çıkarma yoluyla küçülme stratejisi izleyen firmalarda, küçülmeden sonra işten çıkarılmayan çalışanların adalet algılarının firmalarına karşı hissettikleri duygusal bağlllı üzerindeki etkilerini incelemektedir. Örneklem, hizmet sektöründe faaliyet gösteren firmalardan seçilmiştir. Yapllan istatistiksel analiz neticesinde, hizmet sektöründe prosedür adaleti işten çıkarılmayanların duygusal bă̆lılıkları üzerinde etkili değil iken, dă̆ıtım adaletinin işten çıkarılmayanların duygusal bağlllıkları üzerinde etkili olduğu bulunmuştur. Analiz sonucunda ayrıca, etkileşim adaletinin işten çıkarılmayanların duygusal bağglllkları üzerinde kuvvetli bir pozitif etkiye sahip olduğu da tespit edilmiştir. Çalışmanın teorik ve pratik sonuçları da tartışılmıştır.

Anahtar kelimeler : dă̆ıtım adaleti, prosedür adaleti, etkileşim adaleti, duygusal bağlılık.

Turkey has been confronted with a series of deep economic crises in the last 14 years, two of them in 1994, 1999, and the last one in 2001. These crises affected all major industrial sectors (Zehir, 2005). Although the consequences of the crises varied across firms and industries, the threat it presented was

* Dr. Alper Ertürk is an instructor in the Naval Sciences and Engineering Institute at Turkish Naval Academy, 34944, Tuzla, Istanbul, Turkey. E-mail: yeldaalper@yahoo.com 
nationwide. Therefore, firms had to adjust their strategies in order to cope. Employee downsizing was preferred by most companies attempting to cope with fundamental structural changes in this crisis situation. In other words, employee downsizing was realized as the only feasible restructuring strategy in the short term during the February 2001 crisis.

Employee downsizing can be defined as intentionally and strategically laying off employees during times of economic crisis (Filatotchev et al., 2000). Employee downsizing is a systematic reduction of a workforce by an employer, usually as a result of financial losses, cash flow difficulties, loss of government contracts, technological changes, or international competition (Applebaum, Simpson and Shapiro, 1987). Companies downsize by terminating or transferring employees, offering early retirement, or imposing hiring freezes (Tang and Fuller, 1995). It is understandable why executives in a crisis choose downsizing. Labor costs are one of the largest expenses. Layoffs are also a management consultant's dream that can yield immediate financial results and rescue the company. Thus, downsizing is a short-term "money maker" (Rayburn, 1999).

Compared to portfolio and financial restructuring strategies, which have received considerable attention in the strategic restructuring literature, organizational downsizing is still relatively underresearched (Bowman et al., 1999). However, employee downsizing has been identified as a distinctive and important element of strategic choice aimed at bringing a firm's output in line with demand through permanent reductions in human resources (Filatotchev et al., 2000). Researchers have not focused on labor retrenchment as a mode of restructuring and in general "downsizing is probably the most pervasive yet under-studied phenomenon in the business world" (Cameron, 1994: 183).

Prior research has shown that downsizing can have strong effects on survivors' (those who remain employed subsequent to downsizing) behavior, such as job involvement (Allen, et al., 2001; Brockner et al., 1988), organizational citizenship behaviors (Bies et al., 1993) and work effort (Brockner et al., 1992a). Although a great deal is known about survivors' immediate reactions to downsizing, such as job involvement and work effort, little is known about survivors' longer-term behavioral responses, particularly in terms of their willingness to remain in the organization or organizational commitment.

Most research about downsizing and its effect on employees has been realized in the western empirical context. So as a different perspective, this article focuses on the effect of employees' justice perceptions on their organizational commitment under conditions of job-insecurity created by considerable employee layoffs in Turkey. Our aim is to examine the effect of managerial fairness on survivors' organizational commitment to their organization while experiencing the downsizing in the organization. In the theoretical model, it is explicitly emphasized that employees' justice perceptions will be positively associated with survivors' organizational commitment.

Accordingly, the present study explores the relationship between perceived organizational fairness and affective commitment across blue-collar workers who remain employed after layoffs in five different service companies in Turkey. The data were collected during the most influential days of the February 2001 economic crisis. Therefore, the present sampling context represents a unique opportunity to explore the relationship between fairness perceptions and the commitment of employees -layoff survivors-, under highly unstable economic conditions and strong feelings of job insecurity. Indeed, in the companies chosen as the sample substantial employee layouts had been realized shortly before or during the data collection. 
Most of the literature on organizational psychology has been focused on western countries, which have relatively more stable economic conditions. Especially, research in work-related psychology, conducted in different cultural context and economic conditions, is weak and has a lot of room for expansion, innovation and improvement (Glazer, 2002). After the economic crises in the late 1990s, Turkey went through a major change process in the strategies and structures of public and private organizations. Thus, those changes in the business environment created new opportunities for researchers to test and validate the applicability of organizational psychology theories in different economic conditions. So, results from Turkish samples provide valuable insights for practicing business managers in Middle Eastern and Central Asian countries, where research is almost non-existent. Testing the cross-national applicability of western-based management theories on Turkish employees may also provide benefits to Turkish managers and the strategic alliances between foreign-owned firms and existing Turkish firms.

\section{ORGANIZATIONAL JUSTICE}

Cropanzano and Greenberg (1997) have noted that organizational justice was one of the primary topics of interest during the 1990s for scientists in industrial-organizational psychology, human resources management, and organizational behavior. They also indicate that this interest continues today and shows no sign of decreasing in the foreseeable future. Furthermore, recent research (Martin and Bennett, 1996) suggests that justice perceptions are critical for understanding the emergence of behavioral dimensions, such as commitment. Moorman (1991: 845) states that, "In essence, the belief of researchers who support the value of organizational justice is if employees believe that they are treated fairly, they will be more likely to hold positive attitudes about their work, work outcomes and their supervisors."

"Organizational justice" is the term used to describe the role of fairness as it directly relates to the workplace (Greenberg, 1987). Specifically, organizational justice focuses on the ways in which employees determine if they have been treated fairly in their jobs and the ways in which those perceptions influence other organizational outcomes (Alexander and Ruderman, 1987; Fryxell and Gordon, 1989; Greenberg, 1990a; Moorman, 1991).

Organizational justice theory (Greenberg, 1990b) posits that employees' feelings of equity in the workplace are determined mainly by (a) how decisions affecting them are made, and (b) the outcomes of these decisions. This theory also holds that employees judge whether the decisional processes and mechanisms (procedural justice) and the consequences of those decisions are fair (distributive justice). Greenberg (1990b) also argues that procedural and distributive justice are independent determinants of perceived fairness that are typically distinguished from each other. In practice, however, the two are usually positively associated. Subsequently, Tyler and Bies (1990) suggest that the strength of the perceived procedural-distributive justice relationship varies widely: it is stronger among employees committed to their organization and weaker among those who value their membership much less.

If employees perceive the outcome allocation to be fair or perceive the procedures on which outcome allocation decisions are based to be fair, they will likely reciprocate by showing behaviors that go beyond the in-role performance of their jobs (Niehoff and Moorman, 1993). Similarly, fair treatment by management also demonstrates respect for the rights and dignity of employees, leading to the development of trust (Folger and Konovsky, 1989). 
It is therefore reasonable to assert that the specific antecedent justice factors that give rise to organizational commitment, as well as the relative effect of each antecedent factor, will be dependent upon a variety of situational factors pertaining to the organizational and general environmental context. Concerning the relative effects of fairness perceptions, economic conditions affecting feelings of job security, wage stability, and long-term predictability are critical contingency factors determining the importance of each justice category. That is, under highly unstable economic conditions employee perceptions of managerial fairness could vary through effects on organizational commitment after downsizing. Our data, collected just after the February 2001 economic crisis, represent a unique job environment in which massive employee layoffs and wage reductions took place in the sampled industrial establishments.

Studies indicate that cross-cultural differences exist in justice perceptions. In a sample from Mexico, Konovsky, Elliot and Pugh (1995) found distributive justice was more important than procedural justice in predicting citizenship behavior. Konovsky and Pugh (1994) found the opposite in a sample from the United States, where procedural justice, not distributive justice, predicted citizenship behavior. Similarly, Pillai and Williams (1999) found that procedural justice was a stronger predictor of trust in Germany. Collectively, the studies reviewed above indicate similarity across cultures in the predictors of justice judgments, but different findings could be yielded in the consequences of justice dimensions across different cultures. Moreover, Greenberg (2001) also suggests that people may have different perceptions of fairness because they have internalized different norms and values, and a major reason why people differ with respect to norms and values is that they come from different cultures.

\section{Distributive Justice}

Most of the early organizational justice research focused on distributive justice, which reflects the perceived fairness of pay and other rewards received. Since its focus is on outcome fairness, Adams' $(1963 ; 1965)$ equity theory has been commonly used to operationalize the construct. Equity theory emphasizes an employee's beliefs of how he or she is treated in relation to others. The perceived ratio of what an employee puts into his/her job is one of the factors helping to determine equity or inequity. When an employee is evaluating whether an outcome is appropriate or fair in comparison to others, he or she is making a distributive justice decision (Folger and Cropanzano, 1998).

Due to its focus on outcomes, distributive justice is predicted to be related mainly with the person's emotions (e.g., happiness or pride), cognitions (e.g., cognitively distort inputs and outcomes of oneself or the other) and their behavior (e.g., performance and withdrawal) (Weiss, et al., 1999; CohenCharash and Spector, 2001). In general terms, research has shown that distributive justice predicts specific personal outcomes, such as pay satisfaction, better than general organizational outcomes, such as organizational commitment and turnover (Folger and Cropanzano, 1998; Greenberg, 1990; Sweeney and McFarlin, 1993).

\section{Procedural Justice}

The procedural justice perspective focuses on the process used to make decisions about how outcomes are determined (Alexander and Ruderman, 1987; Cropanzano and Schminke, 2001). The procedures used in determining pay raises uniquely contribute to trust in the leader and to organizational commitment (Folger and Konovsky, 1989). 
Furthermore, research has shown that the perceived fairness of the procedures used in making reward allocations are strongly related to authority and institution evaluations, such as organizational commitment (Florkowski and Schuster, 1992; Folger and Konovsky, 1989; Sweeney and McFarlin, 1993; McFarlin and Sweeney, 1992; Scarpello and Jones, 1996; Welbourne, 1998).

Lind and Tyler (1988) suggest that procedural justice is related to more general evaluations of organizations (e.g., trust in supervisor, commitment), whereas distributive justice is related to evaluations of specific outcomes. Similarly, Konovsky and Cropanzano (1991) examined the role of procedural justice perceptions of drug testing programs on employee attitudes (such as job satisfaction and commitment) and found that procedural justice, but not distributive justice, predicted these attitudes.

A review by Greenberg (1990) identifies two components of procedural justice. The first component is fair formal procedures. Having fair procedures for the distribution of rewards or tasks is a fundamental issue in fostering overall fairness perceptions (Leventhal, 1980). The second component of procedural justice is interactional justice. This term refers to the fairness of the treatment an employee receives in the enactment of formal procedures or in the explanation of those procedures (Bies, 1987; Bies and Moag, 1986; Bies and Shapiro, 1987; Tyler and Bies, 1990).

\section{Interactional Justice}

Interactional justice, an extension of procedural justice, refers to the human side of organizational practices, that is, to the way the management behaves toward the recipient of justice (Bies and Moag, 1986; Bies, 1987; Bies and Shapiro, 1987). Therefore, interactional justice relates to the aspects of the communication process between the source (or those controlling rewards and resources) and the recipient of justice, such as politeness, respect and honesty (Bies and Moag, 1986; Tyler and Bies, 1990).

Furthermore, in some research interactional justice is composed of two components, informational and interpersonal justice (Greenberg, 1993; Colquitt et al., 2001). Informational justice refers to "providing knowledge about procedures that demonstrate regard for people's concerns" (Greenberg, 1993: 84) and interpersonal justice refers to "showing concern for individuals regarding the distributive outcome they receive" (Greenberg, 1993: 85).

\section{AFFECTIVE COMMITMENT DURING AND FOLLOWING EMPLOYEE LAYOFFS}

The roots of affective-oriented organizational commitment are based on the theory of Buchanan (1974). Buchanan defines organizational commitment as "a partisan, affective attachment to the goals and values of the organization, to one's role in relation to goals and values, and to the organization for its own sake, apart from its purely instrumental worth" (Buchanan, 1974: 533). Organizational commitment is characterized by three factors: (i) a strong belief in and acceptance of the goals and values of the organization, (ii) Readiness to exert considerable effort on behalf of the organization, and (iii) a strong desire to maintain membership in the organization (Mowday et al., 1982). Meyer and Allen (1991) conceptualized organizational commitment into three components: affective, continuance and normative commitment. 
Affective commitment consists of three components: emotional attachment, identification and involvement. Employees with a strong affective commitment continue their organizational membership because they want to do so. Affective commitment has been found to be positively associated with organizational outcomes, such as high satisfaction, high productivity and lower turnover (Meyer and Allen, 1997; Mathieu and Zajac, 1990).

When an organization engages in downsizing, such a decision affects employees who are adversely affected by being laid off, as well as employees who remain with the organization, often known as survivors. This should be of concern to organizations, given that the remaining employees may experience a change in their commitment to the organization. However, organizations neglect the psychological impact of downsizing on employees who remain after the layoff. Some research has analyzed the effects of layoffs on the individuals who remain after the layoff, the survivors (e.g., Brockner et al., 1987; Brockner, 1988; Mishra and Spreitzer, 1998; Mone, 1997).

During downsizing, reduction in job security, along with a decline of real wages, and continual demands for increased production concur with a general decline of employee commitment to the employing organizations (Bishop, 1999). Research suggests that an organizational downsizing strongly affects survivors' feeling of attachment to the organization, whether or not their job security is threatened (Brockner et al., 1992b). Those employees who survive repeated downsizing are often less loyal and committed to the organization (Hoskisson and Hitt, 1994; Kaye, 1998; Mishra et al., 1998; Filatotchev et al., 2000). Reduction in employee commitment is not surprising given the substantial employee layoffs and deterioration of real wages. This situation is remarkably serious since research shows that organizational commitment has a positive effect on such organizationally valued outcomes as extrarole behaviors, job performance (e.g., Meyer and Allen, 1997; Mathieu and Zajac, 1990), and lower turnover (e.g., Bishop et al., 1997; Mathieu and Zajac, 1990). In some research, it was found that negative attitudinal changes after the layoff, such as lowered commitment to the organization, were reflected in survivors' reduced work performance (Brockner et al., 1987).

Retrenchments and downsizing often result in the demoralization of the workforce, loss of skilled and experienced employees, disruption of production schedules, and an increased probability of unionization or strikes. Losing skilled workers also results in higher training costs when hiring new inexperienced employees. Consistent low wages and layoffs create morale and productivity problems. An organization will find it difficult to achieve its goals if the workforce is dissatisfied and/or demoralized. Lower-paid employees will not be motivated to give their best and thus productivity will decline. The organization then suffers constant problems of turnover, absenteeism, and lower productivity. Employees that survive a layoff receive additional tasks, leaving them little time to be creative (Rayburn, 1999). At least, survivors are likely to experience significant changes in their context following a downsizing, including possibly new job responsibilities, reporting relationships, and changes in processes (Spreitzer and Mishra, 2002; Allen et al., 2001). At the first sign of crisis, if management shows that the organization is prepared to sacrifice its employees easily, then it will be difficult for the organization to keep highly committed employees. This causes poor morale among survivors and additional costs arriving from severance pay, accrued vacation and sick-day payouts, outplacement, pension and benefits payoffs, and administrative costs (Rayburn, 1999). One of the most prevalent factors contributing to unsuccessful restructuring is a lack of commitment by employees (Hersovitch and Meyer, 2002). 
Downsizing may also condition employees to be risk averse, worried that their own jobs will be the next to go. Having experienced or known the fear of downsizing in the past, employees who manage to survive keep their resumes up to date and their commitments to a minimum. Certainly, extensive layoffs cause employees to question their loyalty to their employers. Managers stress the importance of them being loyal to their organization, but fail to exercise loyalty in their relationships with employees. The likely result is demoralized employees fearful of losing their jobs (Rayburn, 1999).

The effects of downsizing have tended to be theoretically euphemized by indicating that the "psychological contract" between employer and employees has been violated and the employer can no longer offer job security (Rousseau, 1995). During the periods of employee layoffs, work relationships can take the form of "backstabbing and placing of blame" (Mohrman and Mohrman, 1983: 459). The impact of psychological contract is also discussed by Meyer and his colleagues (1998), in describing how organizational downsizing affects employee commitment. A psychological contract is essentially an employee's belief about the obligation that exists between him/her and the organization. Thus a key challenge is becoming increasingly clear that a new psychological contract must be created that is not built around the notion of loyalty through lifetime employment (Conger et al., 1999).

\section{MODEL DEVELOPMENT}

\section{The Relationship between Organizational Justice and Organizational Commitment}

Organizational commitment is an identification with and interest in the overall effectiveness and success of the organization (Mowday et al., 1982). Over the past two decades, organizational commitment has become an important research subject.

Both distributive and procedural justice have been linked to organizational commitment in prior research (Folger and Konovsky, 1989; McFarlin and Sweeney, 1992; Konovsky and Cropanzano, 1991). Moreover, Robinson and his colleagues suggest that commitment is dependent on maintaining a relationship of consistency and good faith, which, in turn, is likely to be associated with justice perceptions (Robinson, Draatz and Rousseau, 1994). Similarly, other research has revealed that positive procedural and distributive justice perceptions are associated with increased organizational commitment (Hendrix et al., 1998).

Some other research has found a strong positive correlation among justice dimensions and organizational commitment (Organ, 1994; Cobb and Frey, 1996). However, Lowe and Vodanovich (1995) found that perceptions of the outcome fairness of a job restructuring were more closely related to commitment than were perceptions of the procedural fairness of the restructuring.

Distributive justice ought to influence organizational commitment since an equitable distribution of pay raises strengthens the bonds of loyalty between employees and their company (Folger and Konovsky, 1989). Sweeney and McFarlin (1993) suggest that perceptions of fair procedures are likely to cause workers to have faith in the system, which may lead to higher organizational commitment, regardless of outcomes. More specifically, interpersonal treatment is also likely to be associated with one's satisfaction of the need for praise and approval, which are important determinants of commitment (Mowday, Porter and Steers, 1982). Additionally, interpersonal treatment ought to lead employees to 
feel respected by, and proud of, the organization. In turn, they are more likely to identify with and internalize the values of the organization (Brewer and Kramer, 1996).

Research has shown that procedural justice is important in determining the degree of employees' commitment to the organization (Fields, Pong and Chiu, 2000; Folger and Cropanzano, 1998; Konovsky and Cropanzano, 1991; Schaubroeck, May and Brown, 1994; Sweeney and McFarlin, 1993; Moorman, 1991; Pillai, Schriesheim and Williams, 1999; Moorman, Niehoff and Organ, 1983). Employees perceiving that they have been treated fairly in the process of allocating rewards will be more satisfied with supervisors and display greater organizational commitment. In general, research suggests a link between procedural justice perceptions and organizational commitment.

In a longitudinal study, Tansky (1993) found support for the relationship between perceptions of overall fairness and organizational commitment. She suggests that a "culture of fairness" was responsible for influencing employee attitudes over time. In some research, it was found that justice influence organizational commitment both directly and indirectly through its effects on satisfaction (e.g., Folger and Konovsky, 1989; Kim and Mauborgne, 1993; Konovsky and Cropanzano, 1991).

\section{The Relationship between Justice Perceptions and the Organizational Commitment of Survivors}

Research has shown a relationship between justice perceptions and attitudinal commitment (CohenCharash and Spector, 2001). Studies have shown that the organizational commitment of employees remaining with the organization after downsizing is dependant upon the perceived fairness of the layoffs and/or restructuring (Spreitzer and Mishra, 2002; Brockner, Wiesenfeld and Martin, 1995; Brockner et al., 1993; Brockner et al., 1992a).

In the downsizing context, distributive justice reflects the fairness of the outcomes resulting from the downsizing (Brockner and Greenberg, 1990). Since people are concerned with receiving desired outcomes, attachment and commitment will decrease as desired outcomes become less available. If survivors believe that the victims of the downsizing have received fair outcomes, they will be less likely to consider top management as adversarial, and will feel more commitment to the organization. Another constituent of distributive justice is the extent to which the burden of the downsizing is shared fairly across the levels of organizational hierarchy (Spreitzer and Mishra, 2002). Mostly, survivors are likely to believe that the allocation of scarce resources has been unfair (Brockner and Greenberg, 1990). Sharing the burden of downsizing across organizational levels may create the perception that everyone is in this "together," thus increasing survivors' commitment (Spreitzer and Mishra, 2002). Survivors would have less commitment to the organization if they perceive an unfair layoff. Therefore, it is hypothesized that:

Hypothesis 1: Distributive justice will be positively associated with survivors' affective commitment.

Procedural justice reflects the fairness of the processes and procedures used to implement and realize the downsizing (Brockner and Greenberg, 1990). One important element of procedural justice is the decision rule to determine who is laid off. When this decision rule to determine whom to lay-off is based on a clearly defined decision rule rather than favoritism or politics, a survivor is more likely to appraise the downsizing as more predictable and will feel less threatened. Another important element is advance notice provided about the timing of downsizing. If they have the assurance of advance notice, survivors will know they will be given adequate time to prepare for a downsizing in the near future, if 
necessary (Spreitzer and Mishra, 2002). These attributes will reduce the survivors' perception of threat and create greater commitment. Hence, research has demonstrated that the organizational commitment of survivors is dependent on how they perceive distributive justice, which is defined as looking after those who left the organization, as well as procedural justice, which is defined as whether the organization has provided a clear and reasonable explanation as to why the restructuring or downsizing has occurred (Spreitzer and Mishra, 2002; Brockner, Wiesenfeld and Martin, 1995; Brockner et al., 1993; Brockner et al., 1992a). Therefore, to increase survivors' commitment, determining processes of layoff decisions needs to be fair. So, it is hypothesized that:

\section{Hypothesis 2: Procedural justice will be positively associated with survivors' affective commitment.}

Besides procedural and distributive justice, effective communication between employees and managers is vital. Interactional justice is focused on the interpersonal side of organizational practices, specifically the interpersonal treatment and communication by management to employees, in terms of dignity, respect and politeness. Management must explain fully why and how the layoffs will take place. In terms of interactional justice, first of all, survivors will feel more committed to the organization when the basis of downsizing addresses the circumstances in the external environment, rather than the enrichment of shareholders or top management (Spreitzer and Mishra, 2002; Brockner and Greenberg, 1990). Second, communicating a clear vision of how the downsizing will benefit all stakeholders increases commitment, since survivors can see a clear future for the organization. Third, when survivors are treated with dignity and respect, they will feel more committed to the organization because they feel appreciated, rather than feel blamed (Spreitzer and Mishra, 2002). Brockner and his colleagues (1990) studied the relationship between management's explanation for a layoff and survivors' attitudes toward the organization, and found a strong positive effect on survivor attitudes. Hence, it is hypothesized that:

Hypothesis 3: Interactional justice will be positively associated with survivors' affective commitment.

\section{METHODOLOGY}

\section{Procedure and Sample}

The target population of this study comprised blue-collar employees who remained employed subsequent to downsizing in Turkish service organizations. Five companies from the service sector were chosen randomly from companies that had adopted and implemented employee downsizing strategies and had realized big lay-offs.

All measures were originally developed in English and translated into Turkish via the back-translation technique (see Brislin, 1980). Prior to administering the questionnaire, all questions were revised and adapted to measure justice perceptions and affective commitment related to downsizing. Afterward, a

pilot study was conducted. The results of the pilot study revealed that the scales were easily understood by blue-collar employees.

Questionnaires were sent to each company. A cover letter was used to explain the purpose of the survey and note that participation was voluntary as all participants were assured of confidentiality. 
Moreover, respondents were asked to return the completed questionnaires directly to the research assistant to ensure their anonymity and to avoid a social desirability response bias.

Of the 500 questionnaires sent, 288 completed questionnaires were returned with a response rate of 57\%. After deleting records with missing cases, 278 questionnaires remained and constituted the sample for this study. Some demographic data were also collected, such as age, gender, tenure in the organization and education level. No personal data were collected besides demographics. The average respondent age was 36 (standard deviation of 9.17) and ages ranged from 23 to 64. Sixty-eight percent of the respondents were male and $72 \%$ were married. Survey participants had worked for their organizations for an average of 10.8 years (standard deviation of 6.31 ) and $94 \%$ of the respondents were at least high school graduates. Demographic data are summarized in Table 1.

Table 1

Demographics of the Participants

\begin{tabular}{cccccc}
\hline $\begin{array}{c}\text { Number of } \\
\text { Questionnaires } \\
\text { Analyzed/Sent }\end{array}$ & Age & Sex & $\begin{array}{c}\text { Tenure } \\
\text { (Years) }\end{array}$ & Education & $\begin{array}{c}\text { Marital } \\
\text { Status }\end{array}$ \\
\hline \multirow{2}{*}{$278 / 500$} & Avg. 36 & Male 68\% & Avg. 10.8 & At least High & Married \\
& St.Dev. 9.17 & Female 32\% & St.Dev. 6.31 & School & $72 \%$ \\
& Min. 23 & & & Grads. 94\%. & Single \\
& Max. 64 & & & & $28 \%$ \\
\hline
\end{tabular}

\section{Measures}

All items were measured on a five-point Likert-type scale where $1=$ strongly disagree and 5= strongly agree. Mean scale scores were calculated for all measures. The Cronbach's Alpha was used to estimate reliability for scales.

All organizational justice dimensions were measured with scales adapted from the scales originally developed and tested by Niehoff and Moorman (1993). The distributive justice scale included five items. Six items were used to measure procedural justice and the interactional justice scale included nine items. Organizational commitment was tapped by a scale adapted from the affective commitment scale developed by Meyer and Allen (1991). Affective commitment was assessed by seven items. All items are presented in Table 2.

\section{RESULTS}

\section{Exploratory Factor Analysis and Reliabilities}

Principal factor analysis with varimax rotation was used for each variable to demonstrate the factor structure. Consistent with our expectations, all items loaded with high-standardized coefficients onto their respective factors and with substantially lower standardized coefficients on other factors. Factor loadings of the items in the scales are presented in Table 2. 
Table 2

Factor Loadings of Items in Scales

\begin{tabular}{|c|c|c|c|c|}
\hline & DJ & PJ & $\mathbf{I J}$ & $\mathbf{A C}$ \\
\hline My work schedule after downsizing is fair & .682 & & & \\
\hline I think that my level of pay after downsizing is fair & .783 & & & \\
\hline I consider my work load after downsizing to be quite fair. & .814 & & & \\
\hline Overall, the rewards I receive as a survivor here are quite fair. & .807 & & & \\
\hline I feel that my job responsibilities after downsizing are fair. & .789 & & & \\
\hline Downsizing decisions are made by the general manager in an unbiased manner. & & .798 & & \\
\hline $\begin{array}{l}\text { My general manager makes sure that all employee concerns are heard before } \\
\text { downsizing decisions are made. }\end{array}$ & & .857 & & \\
\hline $\begin{array}{l}\text { To make downsizing decisions, my general manager collects accurate and complete } \\
\text { information. }\end{array}$ & & .910 & & \\
\hline $\begin{array}{l}\text { My general manager clarifies downsizing decisions and provides additional } \\
\text { information when requested by employees. }\end{array}$ & & .884 & & \\
\hline All downsizing decisions are applied consistently across all affected employees. & & .880 & & \\
\hline $\begin{array}{l}\text { Employees are allowed to challenge or appeal downsizing decisions made by the } \\
\text { general manager. }\end{array}$ & & .788 & & \\
\hline $\begin{array}{l}\text { When downsizing decisions are made, the general manager treats me with kindness and } \\
\text { consideration. }\end{array}$ & & & .843 & \\
\hline $\begin{array}{l}\text { When downsizing decisions are made, the general manager treats me with respect and } \\
\text { dignity. }\end{array}$ & & & .819 & \\
\hline $\begin{array}{l}\text { When downsizing decisions are made, the general manager is sensitive to my personal } \\
\text { needs. }\end{array}$ & & & .832 & \\
\hline $\begin{array}{l}\text { When downsizing decisions are made, the general manager deals with me in a truthful } \\
\text { manner. }\end{array}$ & & & .824 & \\
\hline $\begin{array}{l}\text { When downsizing decisions are made, the general manager shows concern for my } \\
\text { rights as an employee. }\end{array}$ & & & .848 & \\
\hline $\begin{array}{l}\text { Concerning decisions made about downsizing, the general manager discusses the } \\
\text { implications of the downsizing decisions with me. }\end{array}$ & & & .827 & \\
\hline The general manager offers adequate justification for downsizing decisions made. & & & .831 & \\
\hline $\begin{array}{l}\text { When making downsizing decisions, the general manager offers explanations that } \\
\text { make sense to me. }\end{array}$ & & & .840 & \\
\hline My general manager explains very clearly downsizing decisions made. & & & .767 & \\
\hline Even after downsizing, I feel like part of a family at this organization. & & & & .774 \\
\hline Even after downsizing, I feel emotionally attached to this organization. & & & & .755 \\
\hline $\begin{array}{l}\text { Working at this organizaztion as a survivor after downsizing has a great deal of } \\
\text { personal meaning for me. }\end{array}$ & & & & .797 \\
\hline Even after downsizing, I feel a strong sense of belonging to this organization. & & & & .867 \\
\hline I would be happy to work at this organization after downsizing. & & & & .841 \\
\hline I really feel that any problems faced by my organization are also my problems. & & & & .809 \\
\hline Even after downsizing, I enjoy talking about my organization with people outside of it. & & & & 679 \\
\hline $\begin{array}{l}\text { DJ: Distributive Justice, PJ:Procedural Justice, IJ: Interactional Justice, } \\
\text { AC: Affective Commitment }\end{array}$ & & & & \\
\hline
\end{tabular}


The five-item distributive justice measure produced a one-factor solution allowing the retention of all five of its original items. The coefficient alpha of the items was 0.83 . Six items comprising the procedural justice measure also produced a clean single factor solution with the alpha coefficient of 0.92. Also the interactional justice scale comprised of nine items produced a one-factor solution and the alpha coefficient of the interactional justice scale was 0.94 . The affective commitment measure including seven items also exposed a one-factor solution with an alpha coefficient of 0.90. Coefficient alpha estimates for all the scales were greater than the recommended level of 0.70 (Nunnaly, 1978).

\section{Descriptive Statistics and Bivariate Correlations}

Table 3 presents the means, standard deviations, coefficient alpha internal consistency reliabilities and Pearson intercorrelations among the four defined variables. As shown in Table 3, all variables are significantly correlated with each other.

Table 3

Means, Standard Deviations, Reliability Coefficients and Correlations of Scales

\begin{tabular}{|c|c|c|c|c|c|c|}
\hline & Mean & Std. Dev. & DJ & PJ & IJ & $\mathrm{AC}$ \\
\hline DJ & 3.13 & .23 & $.83 a$ & & & \\
\hline PJ & 3.08 & .07 & $.538 * *$ & $.92 \mathrm{a}$ & & \\
\hline IJ & 3.27 & .09 & $.571 * *$ & $.800 * *$ & $.94 a$ & \\
\hline $\mathrm{AC}$ & 3.35 & .07 & $.302 * *$ & $.340 * *$ & $.391 * *$ & $.90 \mathrm{a}$ \\
\hline
\end{tabular}

\section{Regression Analyses}

The hypotheses were tested with regression analyses. Distributive, procedural and interactional justice were independent variables, whereas affective commitment was a dependent variable in the regression model.

The regression model was found to be statistically significant $(\mathrm{F}=17.756, \mathrm{p}<0.01)$. In $\mathrm{H} 1$, it was proposed that higher scores on the perception of distributive justice would be related to stronger affective commitment of survivors to the organization. As expected, distributive justice was found to be significantly related to survivors' organizational commitment $(\beta=0.120, \mathrm{p}<0.05)$. Thus, the first hypothesis that proposed distributive justice would be positively associated with survivors' commitment was supported.

Hypothesis 2 examined the relationship between procedural justice and the organizational commitment of survivors and predicted that higher scores on a measure of procedural justice would be related to stronger organizational commitment. Contrary to the proposition, procedural justice was not found to be significantly associated with affective commitment $(\beta=0.050, p>0.05)$. Accordingly, the regression results indicated that procedural justice was not significantly associated with survivors' commitment. Therefore, the second hypothesis that procedural justice would be associated with survivor's affective commitment was not supported. 
It was also hypothesized (H3) that interactional justice would be positively associated with survivors' organizational commitment. This hypothesis received statistically significant support $(\beta=0.288$, $\mathrm{p}<0.01)$. Therefore, the positive relationship between interactional justice and survivors' organizational commitment was significantly and fully supported. Table 4 summarizes the regression analysis.

Table 4

Regression Coefficients

\begin{tabular}{lccc}
\hline & \multicolumn{3}{c}{$\begin{array}{c}\text { Dependent Variable } \\
\text { Affective Commitment }\end{array}$} \\
\hline Independent Variables & $\beta$ & $\mathbf{t}$ & Sig. \\
\hline Distributive Justice & 0.120 & $2.094^{*}$ & 0.034 \\
Procedural Justice & 0.050 & 0.541 & 0.618 \\
Interactional Justice & 0.288 & $3.000^{* *}$ & 0.001 \\
F & & $17.756^{* *}$ & \\
R2 & & 0.163 & \\
Adjusted R2 & & 0.154 & \\
\hline
\end{tabular}

** Significant at $\mathrm{p}<0.01$.

* Significant at $\mathrm{p}<0.05$

\section{DISCUSSION AND CONCLUSION}

In this study, the main focus was to examine how survivors' justice perceptions affect their commitment, which is a long-term behavioral response, after actual downsizing realized during the 2001 economic crisis in Turkey. The long-term attachment of survivors, such as commitment, is believed to be critical for the organization to turn its performance around following downsizing (Mishra, Spreitzer and Mishra, 1998).

The relationship between distributive justice perceptions and affective organizational commitment among survivors was found to be statistically significant in service organizations. Contrarily, procedural justice was not found to be significantly or positively associated with survivors' affective commitment.

Fairness in the allocation of decisions is vital for organizations realizing a downsizing process. Distributive justice reflects the delivery of the decisions used to implement and realize the downsizing. Since employees put more emphasis on what they see and how fairly the lay-off decisions were realized, the fairness of the allocation of the decisions determining who is going to be laid off is more critical than the fairness of the procedures on which the lay-off decisions are based. So, when the layoff decisions are realized fairly among all employees, a survivor is likely to feel less threatened and more committed.

Interactional justice was found to be significantly and positively related to survivors' organizational commitment. When managers explain clearly the basis of the downsizing decision and how layoffs will take place, survivors feel more committed to the organization. Informing all survivors about how 
the downsizing will benefit all employees increases commitment, since survivors have a clear vision for the organization. Furthermore, courteous and well-mannered treatment will affect survivors' commitment positively.

In an unstable economic situation, like the February 2001 crisis in Turkey, contrary to previous research (e.g., Fields, Pong and Chiu, 2000; Folger and Cropanzano, 1998; Konovsky and Cropanzano, 1991; Schaubroeck, May and Brown, 1994; Sweeney and McFarlin, 1993; Pillai, Schriesheim and Williams, 1999), no significant relationship was found between procedural justice and the affective commitment of survivors under the strong feelings of job insecurity. In a psychological situation like job insecurity, employees might be more strongly affected by what they see or get after the downsizing decisions were made. Especially after downsizing was realized, survivors would care more about the new workload, new responsibilities and new level of pay applied throughout the organization. Thus, the consistency of the distribution of factors brought by the new situation is more important for the survivors after downsizing.

Admittedly, downsizing may be the only option open for an organization facing possible bankruptcy. Under these circumstances, survivors may need some help to stay focused on performing effectively as employees feel insecure because of the layoffs. If survivors believe that the process used to decide who to let go was fair, their productivity and the quality of their job performance may not suffer as much. Certainly, how management handle the termination is important.

Downsizing may affect employees on many levels, resulting in mental and physical disorders, such as depression, anxiety, stress, and diseases like ulcers and hypertension (Tang and Fuller, 1995). It can also affect employees' organizational commitment, loyalty, morale, job satisfaction and productivity. Considering these negative consequences, managers should do everything to avoid those outcomes. They should encourage the participation of employees in the decision-making process, and communicate clearly to employees the purpose of the downsizing decision. Managers can minimize the negative effects by making sure that all layoffs are conducted fairly and ethically. Managers can soften the blow of downsizing by showing consideration, providing adequate explanations and providing organizational justice throughout the organization. Managers should practice such preventive measures as interactional justice. Facilitating perceptions of fairness is critical for influencing the hoped outcomes of downsizing. To help ease some of the stress, managers should make clear to employees which courses of action will improve their lives so more employees can focus on creating value. It is most important for companies to carefully structure their performance appraisal and termination procedures. They should spell out those procedures in writing and clearly communicate them before hiring an employee. This would help employees perceive the organizational justice more clearly.

Organizational commitment will likely decline when the survivors perceive a lack of fairness during the layoffs. Fairness should be one of the foremost thoughts of the senior management team when commencing a downsizing exercise. Individuals perceive organizational justice differently based upon their own personal experiences. However, senior management must convince the employees who remain that the downsizing exercise was a fair procedure. Also, the employees remaining should be given correct and clear information about the rationale of the downsizing. By creating a strong perception of fairness in the organization, management may create a considerable effect on employees and even help reverse some of the negative perceptions that survivors may have about the organization. Because survivors' reactions will vary depending on the fairness perceived during the layoff procedure, management's role is critical to the success of the downsizing process. 
In addition, managers should treat employees with respect. In a highly unstable and insecure job environment, managers should recognize their employees' need for open, honest communication, fair and ethical treatment, and employment support in the event of a layoff. Management must look very carefully at the company's particular situation to determine the best and most ethical route to cut personnel.

Finally, a good long-term managerial relationship with employees is very important, particularly in terms of managerial fairness, beginning long before an announcement to downsize. In this way, effective downsizing is not a short-term treatment, but rather a long-term investment in the human resources of the organization.

The results of this study should be examined with its limitations in mind. First, our framework does not include economic determinants of downsizing decisions. Second, the data are cross sectional and, therefore causality cannot be tested. Third, since all the data used in the study were acquired from the employees themselves as self-report instead of being acquired from the managers, this procedure might have led to a common-method bias. However, to test for common method variance, Harman's one-factor test, a post-hoc remedy that was recommended as providing evidence of the validity of self-report measures, was used (Podsakoff and Organ, 1986). Harman's one-factor test revealed that no one factor emerged to account for the majority of the covariance in the independent and dependent variables, and thus suggested that common method variance is not a problem in our study. Fourth, the generalizability of these results is limited because the study was conducted in five service organizations in Turkey. Finally, other variables that could affect the relationship between the independent and dependent variables were not considered, since the variables other than fairness perceptions and commitment were beyond the scope of this study.

Despite the limitations, it is believed that the study achieved its primary purpose. Moreover, the results of this study demonstrate that it is worthwhile to investigate the underpinnings of work outcomes and behaviors in Turkey. Note that the data were collected from companies that had realized big layoffs during the most influential days of the February 2001 economic crisis. Therefore, the present sampling context represented a unique opportunity to explore the relationship between the fairness perceptions and the organizational commitment of survivors under highly unstable economic conditions and strong feelings of job insecurity.

\section{REFERENCES}

Adams, J.S. (1963). “Toward an Understanding of Inequity," Journal of Abnormal Social Psychology, 67: 422-436.

----- (1965). "Inequity in Social Exchange," in L. Berkowitz (ed.), Advances in Experimental Social Psychology, 2: 267-299. New York: Academic Press.

Alexander, S. and Ruderman, M. (1987). "The Role of Procedural and Distributive Justice in Organizational Behavior," Social Justice and Responsibility, 1: 177-198.

Allen, T.D., Freeman, D.M., Russell, J.E.A., Reizenstein, R.C., and Rentz, J.O. (2001). "Survivor Reactions to Organizational Downsizing: Does Time Ease the Pain," Journal of Occupational and Organizational Psychology, 74: 145-164. 
Applebaum, S., Simpson, R., and Shapiro, B. (1987). “The Tough Test of Downsizing,” Organizational Dynamics, 16(2): 68-79.

Aycan, Z. (2001). "Human Resource Management in Turkey: Current Issues and Future Challenges," International Journal of Manpower, 22(3): 252-260.

Bies, R., Martin, C., and Brockner, J. (1993). "Just Laid Off, but Still a Good Citizen? Only If the Process Is Fair," Employee Rights and Responsibilities Journal, 6: 227-238.

Bies, R.J. and Moag, J.S. (1986). “Interactional Justice: Communication Criteria of Fairness,” in R.J. Lewicki, B.H. Sheppard, and M.H. Bazerman (eds.), Research on Negotiations in Organizations, 1: 43-55. Greenwich, CT: JAI Press.

Bies, R.J. and Shapiro, D.L. (1987). "Interactional Fairness Judgments: The Influence of Causal Accounts," Social Justice Research, 1: 199-218.

Bies, R.J. (1987). “The Predicament of Injustice: The Management of Moral Outrage,” in L.L. Cummings, and B.M. Staw (eds.), Research in Organizational Behavior, 9: 289-319. Greenwich, CT: JAI Press.

Bishop, J.W., Scott, K.D., and Casino, L.S. (1997). “The Differential Effects of Team Commitment and Organizational Commitment on Job Performance and Intention to Quit." Paper presented at the Annual Meeting of the Academy of Management, Boston.

Bishop, J.W. (1999). "Do Layoff Practices Matter? Their Relationship to Commitment and Perceived Organizational Support of Permanent and Temporary Employees," Academy of Strategic and Organizational Leadership Journal, 3(2): 29-38.

Bowman, E.H., Singh, H., Useem, M., and Bhadury, R. (1999). "When Does Corporate Restructuring Improve Economic Performance?” California Management Review, 41(2): 33-54.

Brewer, M.B. and Kramer, R.M. (1986). "Choice Behavior in Social Dilemmas: Effects of Social Identity, Group Size and Decision Framing," Journal of Personality and Social Psychology, 50: 543549.

Brislin, R.W. (1980). "Translation and Content Analysis of Oral and Written Materials," in H.C. Triandis and J.W. Berry (eds.), Handbook of Cross-Cultural Psychology, 2: 389-444). Boston: Allyn and Bacon.

Brockner, J., Grover, S.L., Reed, T.F., DeWitt, R.L., and O’Malley, M.N. (1987). “Survivors' Reactions to Layoffs: We Get by with a Little Help for Our Friends,” Administrative Science Quarterly, 32: 526-541.

Brockner, J. (1988). "The Effects of Work Layoffs on Survivors: Research Theory, and Practice," in B.M. Staw and L.L. Cummings (eds.), Research in Organizational Behavior, 10:213-255), Greenwich, CT: JAI Press.

Brockner, J., Grover, S.L., and Blonder, M.D. (1988). "Predictors of Survivors' Job Involvement Following Layoffs: A Field Study,” Journal of Applied Psychology, 73: 436-442. 
Brockner, J., DeWitt, R.L., Grover, S.L., and Reed, T.F. (1990). "When It Is Especially Important to Explain Why: Factors Affecting the Relationship between Managers' Explanations of a Layoff and Survivors' Reactions to the Layoff," Journal of Experimental Social Psychology, 26(5): 389-407.

Brockner, J. and Greenberg, J. (1990). "The Impact of Layoffs on Survivors: An Organizational Justice Perspective," in J.S. Carroll (ed.), Applied Social Psychology and Organizational Settings: 45-75. Hillsdale, NJ: Erlbaum.

Brockner, J., Grover, S.L., Reed, T.F., and DeWitt, R.L. (1992a). "Layoffs, Job Insecurity, and Survivors' Work Effort: Evidence of an Inverted-u Relationship," Academy of Management Journal, 35: 413-425.

Brockner, J., Tyler, T.R., and Cooper-Schneider, R. (1992b). "The Influence of Prior Commitment to an Institution on Reaction to Perceived Unfairness: The Higher They Are the Harder They Fall," Administrative Science Quarterly, 37: 241-261.

Brockner, J., Wiesenfeld, B.M., Reed, T.F., Grover, S., and Martin, C.L. (1993). "Interactive Effect of Job Content and Context on the Reactions of Layoff Survivors," Journal of Personality and Social Psychology, 64: 187-197.

Brockner, J., Wiesenfeld, B.M., and Martin, C.L. (1995). "Decision Frame, Procedural Justice, and Survivors' Reactions to Job Layoffs," Organizational Behavior and Human Decision Processes, 63: 59-68.

Buchanan, B. (1974). "Building Organizational Commitment: The Socialization of Managers in Work Organizations," Administrative Science Quarterly, 19: 533-546.

Cameron, K.S. (1994). "Investigating Organizational Downsizing Fundamental Issues, Human Resource Management, 33(2): 183-188.

Cobb, A.T. and Frey, F.M. (1996). "The Effects of Leader Fairness and Pay Outcomes on Superior/ Subordinate Relations," Journal of Applied Social Psychology, 26: 1401-1426.

Cohen, J. and Cohen, P. (1983). Applied Multiple Regression/Correlation Analysis for the Behavioral Sciences, $2^{\text {nd }}$ ed. Hillsdale, NJ: Lawrence Erlbaum.

Cohen-Charash, Y. and Spector, P. (2001). "The Role of Justice in Organizations: A Meta Analysis," Organizational Behavior and Human Decision Processes, 86(2): 278-321.

Colquitt, J.A., Conlon, D.E., Wesson, M.J., Porter, C., and Ng, K.Y. (2001). "Justice at the Millennium: A Meta-analytic Review of 25 Years of Organizational Justice Research," Journal of Applied Psychology, 86: 425-445.

Conger, J.A., Spreitzer, G.M., and Lawler III, E.E. (1999). Leader's Change Handbook: An Essential Guide to Setting Direction and Taking Action. San Francisco, CA: Jossey-Bass Publishers. 
Cropanzano, R. and Greenberg, J. (1997). "Progress in Organizational Justice: Tunneling through the Maze," in C.L. Cooper and I.I. Robertson (eds.), International Review of Industrial and Organizational Psychology, 12: 317-372. New York: John-Wiley.

Cropanzano, R. and Schminke, M. (2001). "Using Social Justice to Build Effective Work Groups," in M. Turner (ed.), Groups at Work: Theory and Research: 143-171. Hillsdale, NJ: Erlbaum.

DeWitt, R.L. (1998). "Downsizing Strategically," in D.L. Katchen (ed.), Advances in Applied Business Strategy: 21-36. Greenwich: CT: JAI Press.

Fields, D., Pong, M., and Chiu, C. (2000). "Distributive and Procedural Justice as Predictors of Employee Outcomes in Hong Kong," Journal of Organizational Behavior, 21: 547-562.

Filatotchev, I., Buck, T., and Zhukov, V. (2000). "Downsizing in Privatized Firms in Russia, Ukraine and Belarus," Academy of Management Journal, 43(3): 286-304.

Florkowski, G.W. and Schuster, M.H. (1992). "Support for Profit Sharing and Organizational Commitment: A Path Analysis," Human Relations, 45: 507-523.

Folger, R. and Cropanzano, R. (1998). Organizational Justice and Human Resource Management. Beverly Hills (CA): Sage.

Folger, R. and Konovsky, M.A. (1989). "Effects of Procedural and Distributive Justice on Reactions to Pay Decisions," Academy of Management Journal, 32: 115-130.

Fryxell, G.E. and Gordon, M.E. (1989). "Workplace Justice and Job Satisfaction as Predictors of Satisfaction with Union and Management," Academy of Management Journal, 32: 851-866.

Glazer, S. (2002). "Past, Present and Future of Cross-cultural Studies in Industrial and Organizational Psychology," in C. Cooper and I.T. Robertson (eds.), International Review of Industrial and Organizational Psychology: 17. Chichester, UK: Wiley.

Greenberg. J. (1987). “A Taxonomy of Organizational Justice Theories,” Academy of Management Review, 12: 9-22.

----- (1990a). “Organizational Justice: Yesterday, Today and Tomorrow,” Journal of Management, 16: 399-432.

------ (1990b). "Looking Fair versus Being Fair: Managing Impressions of Organizational Justice," in B.M. Staw and L.L. Cummings (eds.), Research in Organizational Behavior, 12: 111-157, Greenwich, CT: JAI Press.

----- (1993). "The Social Side of Fairness: Interpersonal and Informational Classes of Organizational Justice," in R. Cropanzano (ed.), Justice in the Workplace: Approaching Fairness in Human Resource Management: 79-103. Hillsdale, NJ: Erlbaum. 
(2001). "Studying Organizational Justice Cross-culturally: Fundamental Challenges," The International Journal of Conflict Management, 12(4): 365-375.

Hendrix, W.H., Robbins, T., Miller, J., and Summers, T.P. (1998). "Effects of Procedural and Distributive Justice on Factors Predictive of Turnover," Journal of Social Behavior and Personality, 13: 611-633.

Hersovitch, L. and Meyer, J.P. (2002). "Commitment to Organizational Change: Extension of a Threecomponent Model," Journal of Applied Psychology, 87: 474-487.

Hoskisson, R.E and Hitt, M.A. (1994). Downscoping: How to Tame the Diversified Firm. New York: Oxford University Press.

Kaye, B.L. (1998). “The Kept-on Workforce,” Training and Development, March, 52(3): 32-38.

Kim, W.C. and Mauborgne, R.A. (1993). "Procedural Justice, Attitudes and Subsidiary Top Management Compliance with Multinationals' Corporate Strategic Decision," Academy of Management Journal, 36: 502-526.

Konovsky, M.A. and Cropanzano, R. (1991). "Perceived Fairness of Employee Drug Testing as a Predictor of Employee Attitudes and Job Performance," Journal of Applied Psychology, 76: 698707.

Konovsky, M.A. and Pugh, S.D. (1994). "Citizenship Behavior and Social Exchange,” Academy of Management Journal, 37: 656-669.

Konovsky, M.A., Elliott, J., and Pugh, S.D. (1995). "Citizenship Behavior and Its Determinants in Mexico." Paper Presented at The National Academy of Management Meetings, Vancouver, Canada.

Konovsky, M.A. (2000). "Understanding Procedural Justice and Its Impact on Business Organizations," Journal of Management, 26: 489-511.

Leventhal, G.S: (1980). "What Should Be Done with Equity Theory? New Approaches to the Study of Fairness in Social Relationships," in K.S. Gergen, M.S. Greenberg, and R.H. Willis (eds.), Social Exchange: Advances in Theory and Research: 27-55. New York: Plenum Press.

Lind, E.A., and Tyler, T.R. (1988). The Social Psychology of Procedural Justice. New York: Plenum Press.

Lowe, R.H. and Vodanovich, S.J. (1995). "A Field Study of Distributive and Procedural Justice as Predictors of Satisfaction and Organizational Commitment," Journal of Business and Psychology, 10: 99-114.

Martin, C.L. and Bennett, N. (1996). "The Role of Justice Judgmnts in Explaining the Relationship between Job Satisfaction and Organizational Commitment," Group and Organization Management, 21: 84-104. 
Mathieu, J.E. and Zajac, D.M. (1990). "A Review and Meta-analysis of the Antecedents, Correlates and Consequences of Organizational Commitment, Psychological Bulletin, 108: 171-194.

McKinley, W., Zhao, J., and Rust, K.G. (2000). “A Socio-cognitive Interpretation of Organizational Downsizing," Academy of Management Review, 25: 227-243.

McFarlin, D.B. and Sweeney, P.D. (1992). "Distributive and Procedural Justice as Predictors of Satisfaction with Personal and Organizational Outcome," Academy of Management Journal: 35, 626637.

Meyer, J.P. and Allen, N.J. (1991). “A Three-component Conceptualization of Organizational Commitment," Human Resource Management Review, 1: 61-89.

Meyer, J.P. and Allen, N.J. (1997). Commitment in the Workplace: Theory, Research and Application. Thosand Oaks, CA: Sage Publication.

Meyer, J.P., Allen, N.J. and Topolnytsky, L. (1998). "Commitment in a Changing World of Work," Canadian Psychology, 39: 83-93.

Mishra, K., Spreitzer, G.M., and Mishra, A. (1998). "Preserving Employee Morale during Downsizing," Sloan Management Review, 39: 83-95.

Mishra, K. and Spreitzer, G.M. (1998). "Explaining How Survivors Respond to Downsizing: The Roles of Trust, Empowerment, Justice and Work Redesign," Academy of Management Review, 23: 567-588.

Mohrman, S.A. and Mohrman, A.M., Jr. (1983). "Employee Involvement in Declining Organizations," Human Resources Management, 22(4): 445-465.

Mone, M.A. (1997). "How We Get Along after the Downsizing: Post-downsizing Trust as a Doubleedged Sword," Public Administration Quarterly, 21: 309-336.

Moorman, R.H. (1991). "Relationship between Organizational Justice and Organizational Citizenship Behaviors: Do Fairness Perceptions Influence Employee Citizenship?” Journal of Applied Psychology, 76: 845-855.

Moorman, R.H., Niehoff, B.P., and Organ, D.W. (1993). “Treating Employees Fairly and Organizational Citizenship Behavior: Sorting the Effects of Job Satisfaction, Organizational Commitment and Procedural Justice," Employees Responsibilities and Rights Journal, 6: 209-225.

Mowday, R.T., Porter, L.W., and Steers, R. (1982). Organizational Linkages: The Psychology of Commitment, Absenteeism, and Turnover. San Diego, CA: Academic Press.

Niehoff, B.P. and Moorman, R.H. (1993). "Justice as a Mediator of the Relationship between Methods of Monitoring and Organizational Citizenship Behavior," Academy of Management Journal, 36: 527556 
Nunnally, J.C. (1978). Psychometric Theory. New York: McGraw-Hill.

Organ, C. (1994). "The Effect of Organizational Commitment on the Relationship between Procedural and Distributive Justice,” Journal of Social Psychology, 134: 135-140.

Pillai, R., Schriesheim, C.A., and Williams, E.S. (1999). "Fairness Perceptions and Trust as Mediators for Transformational and Transactional Leadership: A Two-sample Study," Journal of Management, 25: 897-933.

Pillai, R. and Williams, E.S. (1999). "Are the Scales Tipped in Favor of Procedural or Distributive Justice? An Investigation of the U.S., India and Germany." Paper Presented at the National Academy of Management Meetings, Chicago, IL.

Podsakoff, P.M. Organ, D.W. (1986). "Self-reports in Organizational Research: Problems and Prospects," Journal of Management, 12: 531-544.

Rayburn, J.M. (1999). “The Impact of Downsizing,” Academy of Strategic and Organizational Leadership Journal, 3(2): 64-73.

Robinson, S.L., Draatz, M.S., and Rousseau, D.M. (1994). "Changing Obligations and the Psychological Contract: A Longitudinal Study," Academy of Management Journal, 37: 137-152.

Rousseau, D. (1995). Psychological Contracts in Organizations: Understanding Written and Unwritten Agreements. Thousand Oaks, CA: Sage.

Scarpello, V. and Jones, F.F. (1996). "Why Justice Matters in Compensation Decision Making," Journal of Organizational Behavior, 17: 285-299.

Schaubroeck, J., May, D.R., and Brown, F.W. (1994). "Procedural Justice Explanations and Reactions to Economic Hardship: A Field Experiment," Journal of Applied Psychology, 79: 455-460.

Sronce, R. and McKinley, W. (2003). "Perceptions of Organizational Downsizing." Paper Presented at the 65th Annual Conference of German-Speaking Business Economists, University of Zurich, Zurich, Switzerland, June 11.

Spreitzer, G.M. and Mishra, A.K. (2002). "To Stay or to Go: Voluntary Survivor Turnover Following an Organizational Downsizing," Journal of Organizational Behavior, 23:707-729.

Sweeney, P.D. and McFarlin, D.B. (1993). "Workers' Evaluations of the 'Ends' and 'Means': An Examination of Four Models of Distributive and Procedural Justice," Organizational Behavior and Human Decision Processes, 55: 23-40.

Tang, T.L.P. and Fuller, R.M. (1995). "Corporate Downsizing: "What Managers Can Do to Lessen the Negative Effects of Layoffs," SAM Advanced Management Journal, 60(4): 12. 
Tansky, J.W. (1993). “Justice and Organizational Citizenship Behavior: What Is the Relationship?" Employee Responsibilities and Rights Journal, 6: 195-207.

Tyler, T.R. and Bies, R.J. (1990). "Beyond Formal Procedures: The Interpersonal Context of Procedural Justice," in J.S. Carroll (ed.), Applied Social Psychology and Organizational Settings: 7798. Hillsdale, NJ: Erlbaum.

Weiss, H.M., Suckow, K., and Cropanzano, R. (1999). "Effects of Justice Conditions on Discrete Emotions," Journal of Applied Psychology, 84: 786-794.

Welbourne, T.M. (1998). "Untangling Procedural and Distributive Justice: Their Relative Effects on Gain Sharing Satisfaction," Group and Organization Management, 23: 325-346.

Zehir, C. (2005). "The Activation Level of Crises and the Change of Strategic Targets of Enterprises in Turkey during the Depression Era," The Journal of American Academ Business, 6(2). 